Prepared for the U.S. Department of Energy under Contract DE-AC05-76RL01830

\title{
Effect of A-site Non-stoichiometry on LSCF Cathodes
}

$\begin{array}{ll}\text { J.W. Templeton } & \text { J.W. Stevenson } \\ \text { Z. Lu } & \text { J.S. Hardy }\end{array}$

Pacific Northwest National Laboratory, Richland, WA

September 2011

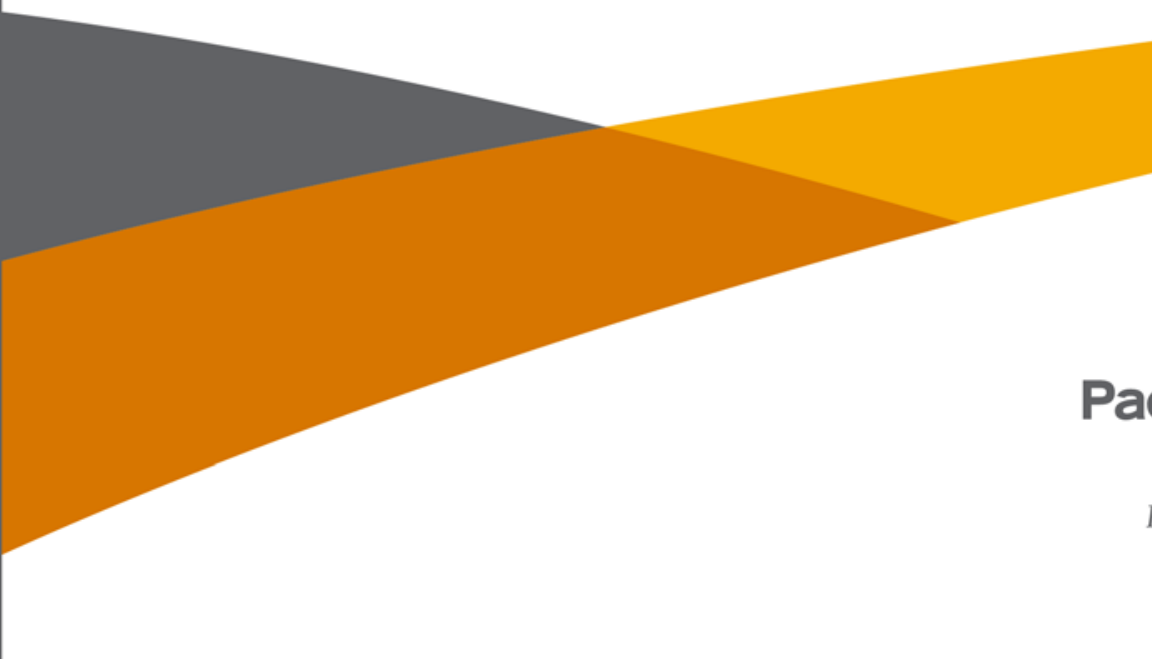




\title{
DISCLAIMER
}

This report was prepared as an account of work sponsored by an agency of the United States Government. Neither the United States Government nor any agency thereof, nor Battelle Memorial Institute, nor any of their employees, makes any warranty, express or implied, or assumes any legal liability or responsibility for the accuracy, completeness, or usefulness of any information, apparatus, product, or process disclosed, or represents that its use would not infringe privately owned rights. Reference herein to any specific commercial product, process, or service by trade name, trademark, manufacturer, or otherwise does not necessarily constitute or imply its endorsement, recommendation, or favoring by the United States Government or any agency thereof, or Battelle Memorial Institute. The views and opinions of authors expressed herein do not necessarily state or reflect those of the United States Government or any agency thereof.

\author{
PACIFIC NORTHWEST NATIONAL LABORATORY \\ operated by \\ BATTELLE \\ for the \\ UNITED STATES DEPARTMENT OF ENERGY \\ under Contract DE-AC05-76RL01830
}

Printed in the United States of America
Available to DOE and DOE contractors from the Office of Scientific and Technical Information,
P.O. Box 62, Oak Ridge, TN 37831-0062;
ph: (865) 576-8401
fax: $(865)$ 576-5728
email: reports@adonis.osti.gov

\begin{abstract}
Available to the public from the National Technical Information Service, U.S. Department of Commerce, 5285 Port Royal Rd., Springfield, VA 22161 ph: (800) 553-6847 fax: $(703) 605-6900$ email: orders@ntis.fedworld.gov online ordering: http://www.ntis.gov/ordering.htm
\end{abstract}

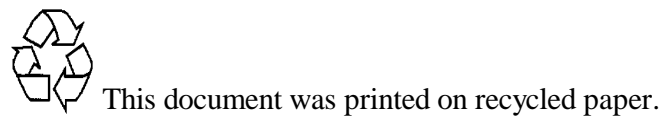




\title{
Effect of A-site Non-stoichiometry on LSCF Cathodes
}

\author{
JW Templeton \\ $\mathrm{Z} \mathrm{Lu}$ \\ JW Stevenson \\ JS Hardy
}

September 2011

Prepared for the U.S. Department of Energy under Contract DE-AC05-76RL01830

Pacific Northwest National Laboratory

Richland, Washington 99352 


\section{Introduction}

At $700-800^{\circ} \mathrm{C}$, the operating temperatures of intermediate temperature (IT-) SOFCs have enabled the use of stainless steels in the SOFC framework and current collectors, allowing significant reductions in cost. However, the lower operating temperatures of IT-SOFC's also result in significant decreases in power densities of cells with LSM cathodes due to their high activation energies. LSCF is a mixed ionicelectronic conducting perovskite that exhibits higher performance than LSM/YSZ composites and shows potential as a replacement cathode ${ }^{1 ; 2}$. This study investigates the effect of A-site stoichiometry on the performance of LSCF cathodes.

\section{Cell Preparation}

$\left(\mathrm{La}_{0.6} \mathrm{Sr}_{0.4}\right)_{1-\mathrm{x}} \mathrm{Co}_{0.2} \mathrm{Fe}_{0.8} \mathrm{O}_{3-\delta}$ and $\mathrm{La}_{0.6} \mathrm{Sr}_{0.4-\mathrm{x}} \mathrm{Co}_{0.2} \mathrm{Fe}_{0.8} \mathrm{O}_{3-\delta}(\mathrm{x}=$ 0, 0.02, 0.05, 0.10 in both cases $)$ powders from Fuel Cell Materials (FCM, Lewis Center, $\mathrm{OH}$ ) were attrition milled to reduce the average particle size to between 0.35-0.40 microns. All cathode inks were made using Heraeus V-006 binder at $40 \%$ solids loading and mixed in a three roll mill. LSCF cathodes with an area of $2 \mathrm{~cm}^{2}$ were screen printed onto anode supported $\mathrm{NiO} / \mathrm{YSZ}$ substrates with a barrier layer consisting of $\mathrm{Sm}_{0.2} \mathrm{Ce}_{0.8} \mathrm{O}_{1.9}$ (samariumdoped ceria, SDC, Praxair Specialty Ceramics) previously sintered at $1200^{\circ} \mathrm{C}$ for 2 hours. The LSCF cathodes were sintered at $1100^{\circ} \mathrm{C}$ for 2 hours. $\mathrm{La}_{0.8} \mathrm{Sr}_{0.2} \mathrm{CoO}_{3}$ (LSC) prepared using the glycine-nitrate process $^{3}$ was screen printed onto the LSCF surface and embedded with Au gauze for cathode current collection. NiO grids with embedded $\mathrm{Ni}$ gauze were used as current collectors for the anode.

Each cell was glass sealed to an alumina tube test stand and tested at $750^{\circ} \mathrm{C}$. Hydrogen with $3 \% \mathrm{H}_{2} \mathrm{O}$ was supplied to the anode at $200 \mathrm{sccm}$ while air or $\mathrm{O} 2$ flowed to the cathode at $400 \mathrm{sccm}$. I-V and impedance spectra were recorded using a Solartron 1470 Multistat in conjunction with a Solartron 1255B frequency response analyzer. After testing, the fuel cells were cross-sectioned for scanning electron microscopy (SEM) (JEOLJSM-5900LV) and energy dispersive x-ray spectroscopy (EDS).

\section{Cell Testing}

Cells were tested under constant current conditions in air for 900-1000 hours with impedance spectroscopy performed every 25-100 hours. First, tests were carried out at the current that corresponded to an operating voltage of $800 \mathrm{mV}$. Then, additional cells were tested at $1.937 \mathrm{~A}$, which was the average current generated at $800 \mathrm{mV}$ at start up of all cells tested to that point in the study. A third test was conducted at 1.937A in oxygen using cells with $\left(\mathrm{La}_{0.6} \mathrm{Sr}_{0.4}\right)_{0.98} \mathrm{Co}_{0.2} \mathrm{Fe}_{0.8} \mathrm{O}_{3-\delta}$ cathodes.

If identical SOFC substrates, on which the cathodes are deposited, were tested at the same constant current and temperature in the same fuel gas environment (fuel composition and flow rates), it could be assumed that the anode's contribution to polarization for each of the cells would be the same. Therefore, any difference in total cell impedance could be attributed to the cathode layer and its interaction with the barrier and electrolyte layers. This method provides a way to compare the performance and stability of various cathode materials against each other by minimizing differences due to anode impedance contributions. In addition, cells tested in oxygen under the same conditions used for tests performed in air would lower the cathode polarization as much as possible and give an indication of the highest possible anode polarization contribution towards the total cell electrode polarization of the tests in air.

\section{Cell Performance}

Figure 1 shows the power density as a function of time for 4 series of tests in air on the 7 LSCF cathode compositions, two at currents corresponding to $800 \mathrm{mV}$ and two at 1.937A. The power density of two 
LSCF cells tested in oxygen, one which had the lowest polarization resistance, and one which showed the least degradation, is also included. Cells using LSCF with A-Site and Sr-deficiencies demonstrated significantly higher performance in both conditions than stoichiometric LSCF cells. However, while performing better than stoichiometric LSCF cells, cells with 10\% Sr-deficient LSCF cathodes performed significantly lower on average than those with other A-site and Sr-deficient compositions. Other than this, no consistent trend in performance with A-site stoichiometry could be concluded from the results. With the exception of the 10\% Sr-deficient LSCF, it appears as though the effects on cell performance are masked by experimental uncertainty. In spite of this, it was obvious that A-site deficiency is beneficial for LSCF cathodes.

Electrode polarization losses were calculated by subtracting the ohmic loss from the total cell resistances measured in impedance scans. Figures 2 and 3 show the ohmic and polarization loses of each LSCF composition tested at $\sim 800 \mathrm{mV}$ (a) and 1.937A (b) respectively. It can be seen that the cell ohmic and polarization resistances generally fall in the same range with no consistent trend with A-site stoichiometry. The two cells tested in oxygen show consistent low electrode polarization resistances which place an upper bound on the anode polarization contribution at $\sim 0.065 \mathrm{ohms}$ based on the discussion above.

\section{Cathode Stability}

Figure 4 shows the degradation rates of the various cathodes when tested at $800 \mathrm{mV}$ and $1.937 \mathrm{~A}$ as calculated from curve fitting the cell performance. Initial degradation rates were very high $(>20 \% / 1000$ hours) for all compositions and declined over time. After 900-1000 hours, the degradation rates were all between 2 and 6\%/1000 hours. As with power density, there was no consistent trend between cathode composition and degradation rate. The two cells tested in oxygen were also included to illustrate the upper bound of the contribution of the anode to the total degradation of the cells. It is also noteworthy that the initial degradation rates of both cells tested in oxygen were lower than those of all cells that were tested in air.

Figure 5 shows back-scattered electron SEM images of polished cross-sections of a 2\% A-site deficient and a $2 \%$ Sr-deficient LSCF cathode. The cathode microstructures seen in Figure 5 are typical of the cathode compositions tested. Strontium is seen at the interface between the SDC and YSZ layers, where it is known to form insulating $\mathrm{SrZrO}_{3}$. Part of the increase in ohmic resistance of the cells during operation may be caused by the diffusion of strontium to the YSZ surface ${ }^{4}$. Figure 6 is an elemental map showing Co distribution in a cross sectional area of $10 \%$ Sr deficient tested cathode. Regions of concentrated cobalt were found in the cathode while maps of other cathode elements appeared to be homogeneous. This Co segregation could, in part, account for the fact that the power density of $10 \% \mathrm{Sr}$ deficient cells was lower on average than the power density of cells with the other compositions. Figure 7 shows the migration of $\mathrm{Sr}$ through the barrier layer where it reacted with the YSZ electrolyte, while Figure 8 illustrates the locations where EDS analysis was performed on the electrolyte. It can be seen that increasing A-Site and Sr vacancies in LSCF generally resulted in a decrease in the amount of Sr which migrated through the barrier layer and into the YSZ electrolyte.

\section{Conclusion}

Cell tests showed that A-site and Sr-deficient LSCF cathodes consistently outperformed stoichiometric LSCF cathodes, exhibiting up to $10 \%$ higher cell power densities . It was also observed that all stoichiometric, A-site, and Sr-deficient LSCF cathodes degraded over time at similar rates. Contributions of ohmic and electrode polarization losses to cell degradation rates were similar regardless of cathode composition. 


\section{Acknowledgments}

The work described in this report was funded through the Solid-State Energy Conversion Alliance (SECA) Core Technology Program by the US Department of Energy's National Energy Technology Laboratory (NETL). Pacific Northwest National Laboratory is operated by Battelle for the U.S. Department of Energy under Contract DE-AC06-76RL01830.

\section{References}

${ }^{1}$ T. Striker, J. A. Ruud, Y. Gao, W. J. Heward, andC. Steinbruchel, "A-site deficiency, phase purity and crystal structure in lanthanum strontium ferrite powders," Solid State lonics, 178[21-22] 1326-36 (2007).

${ }^{2}$ Z. G. Lu, X. D. Zhou, D. Fisher, J. Templeton, J. Stevenson, N. J. Wu, andA. Ignatiev, "Enhanced performance of an anode-supported YSZ thin electrolyte fuel cell with a laser-deposited $\mathrm{Sm}(0.2) \mathrm{Ce}(0.8) \mathrm{O}(1.9)$ interlayer," Electrochemistry Communications, 12[2] 179-82 (2010).

${ }^{3}$ L. A. Chick, L. R. Pederson, G. D. Maupin, J. L. Bates, L. E. Thomas, andG. J. Exarhos, "Glycine Nitrate Combustion Synthesis of Oxide Ceramic Powders," Mater Lett, 10[1-2] 6-12 (1990).

${ }^{4}$ J. S. Hardy, J. W. Templeton, D. J. Edwards, Z. Lu, andJ. W. Stevenson, "Lattice Expansion of LSCF-6428 Cathodes Measured by In-situ XRD during SOFC Operation," Journal of Power Sources[0].

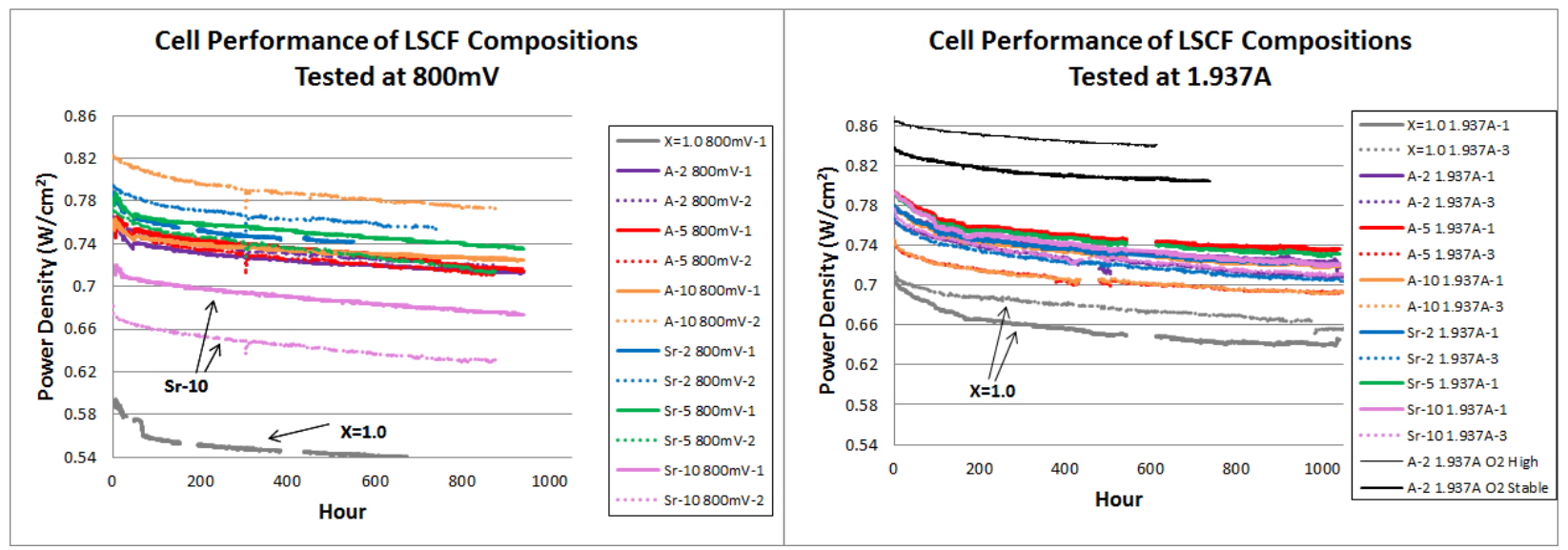

Figure 1. Power density vs. time of LSCF cathode compositions tested at $800 \mathrm{mV}$ (a) and 1.937A (b) 


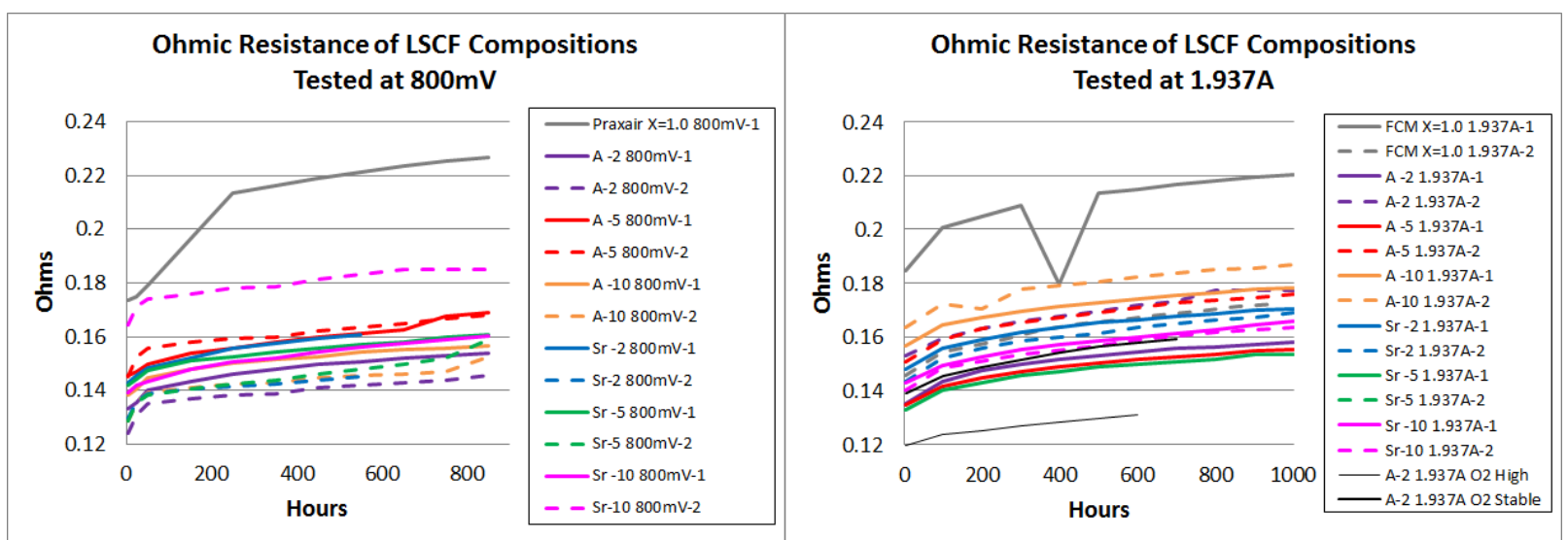

Figure 2. Ohmic Resistance of LSCF cathode compositions tested at $800 \mathrm{mV}$ (a) and 1.937A (b)

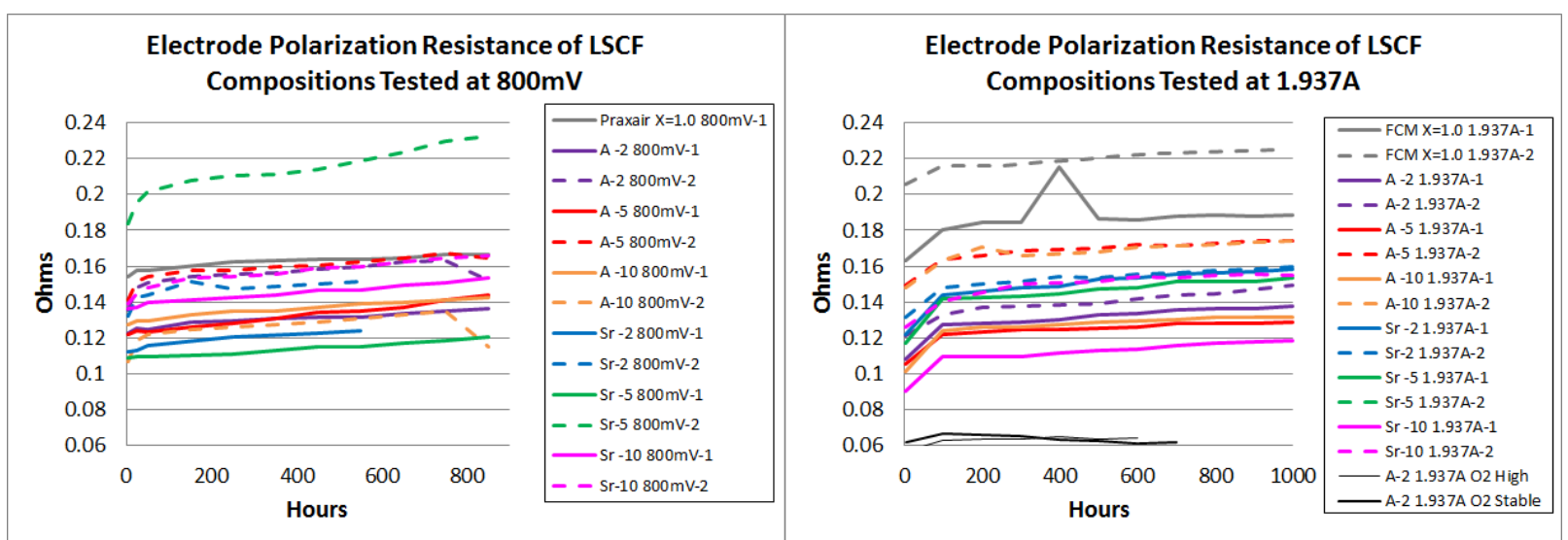

Figure 3. Electrode Polarization resistance of LSCF compositions at $800 \mathrm{mV}$ (a) and 1.937A (b)

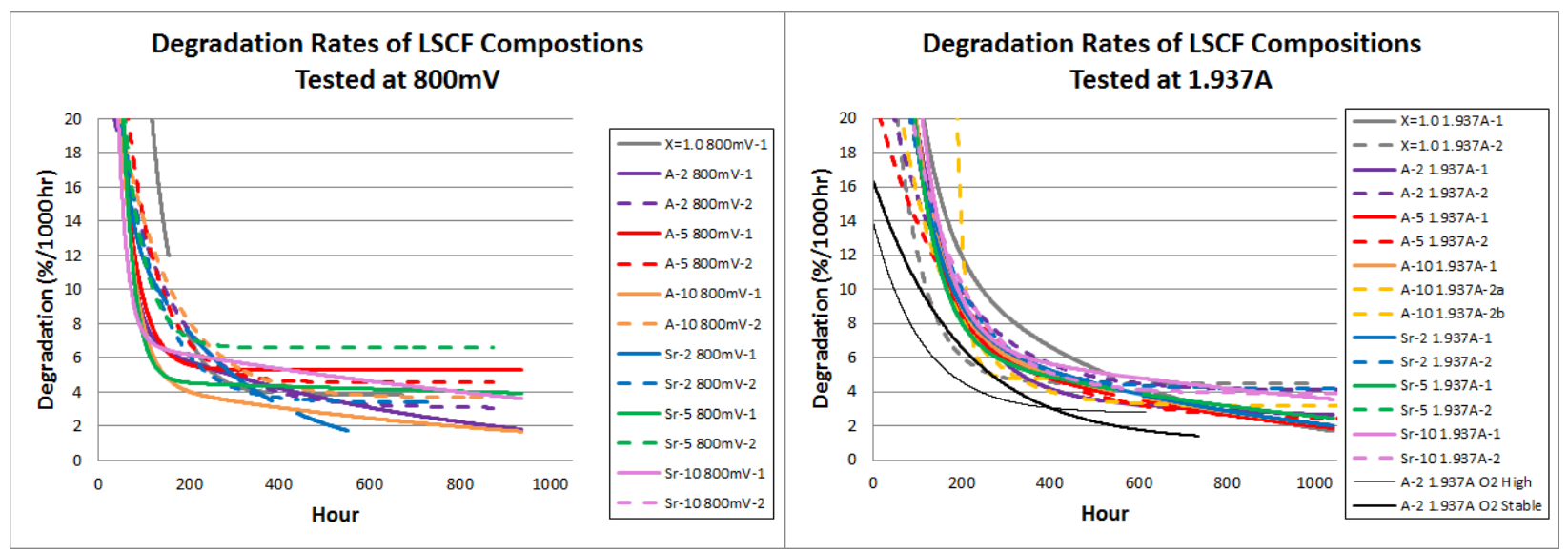

Figure 4. Degradation rates of LSCF cathode compositions tested at 800mV (a) and 1.937A (b) 


\section{A-2 800mV-1}

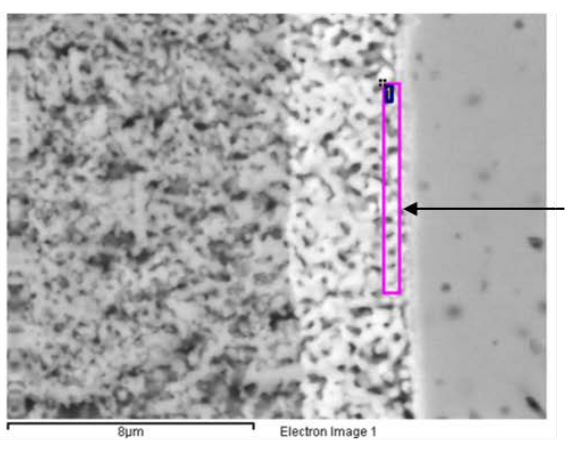

Sr-2 800mV-1

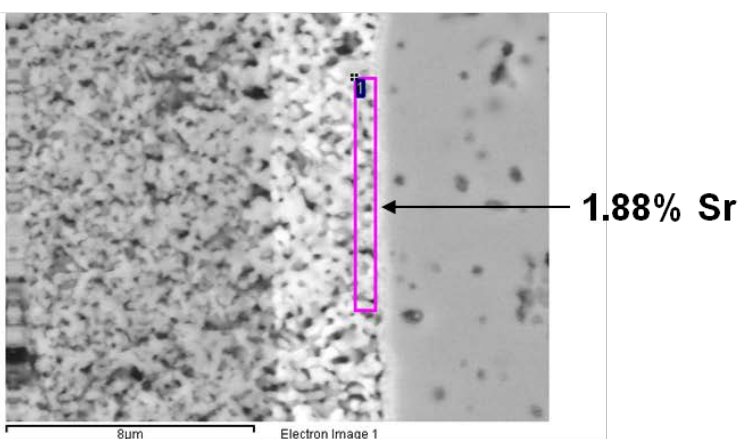

Figure 5. SEM image of 2\% A-site (a) and 2\% Sr-site (b) deficient cells tested at 750C at $800 \mathrm{mV}$
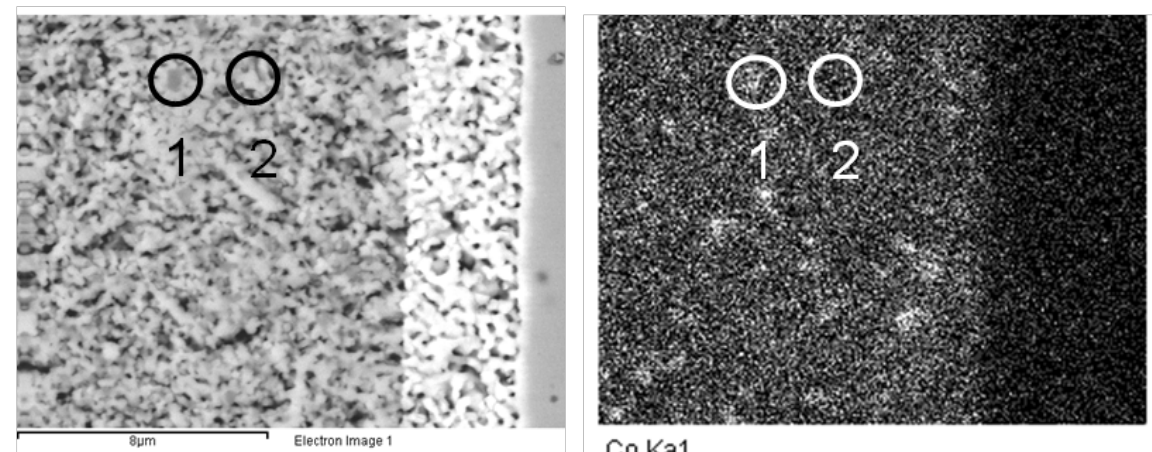

\begin{tabular}{|c|c|c|}
\hline & 1 & 2 \\
\hline $\mathrm{La}$ & $7.80 \%$ & $10.82 \%$ \\
\hline $\mathrm{Sr}$ & $4.35 \%$ & $6.46 \%$ \\
\hline $\mathrm{Co}$ & $\mathbf{8 . 5 4} \%$ & $\mathbf{2 . 5 8} \%$ \\
\hline $\mathrm{Fe}$ & $15.70 \%$ & $12.94 \%$ \\
\hline
\end{tabular}

Co Ka1

Figure 6. SEM image of $10 \% \mathrm{Sr}$ deficient cell tested at $750 \mathrm{C}$ at $800 \mathrm{mV}$

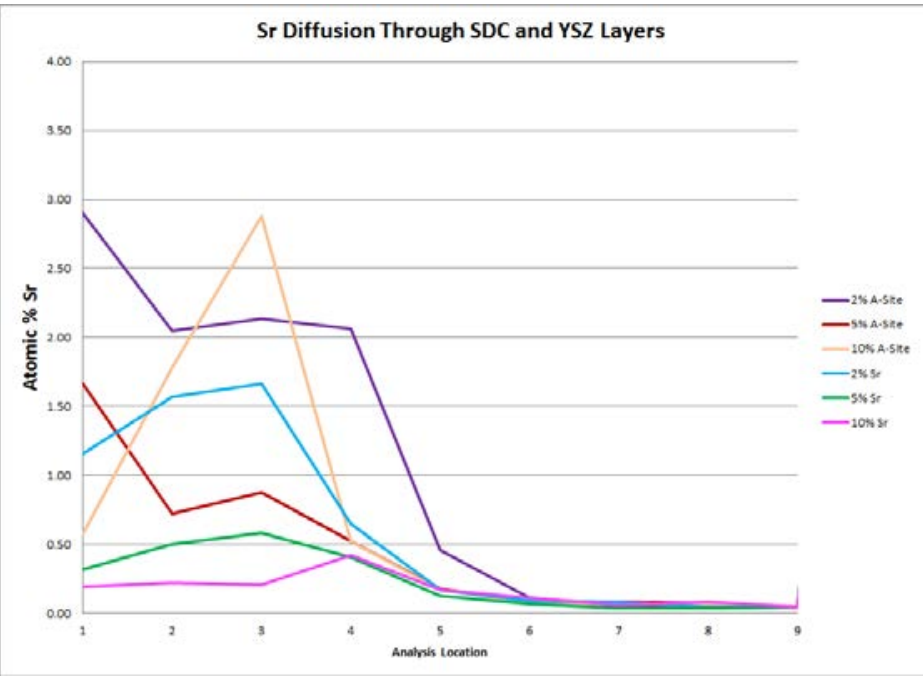

Figure 7. Linear distribution of Sr through YSZ electrolyte layer 


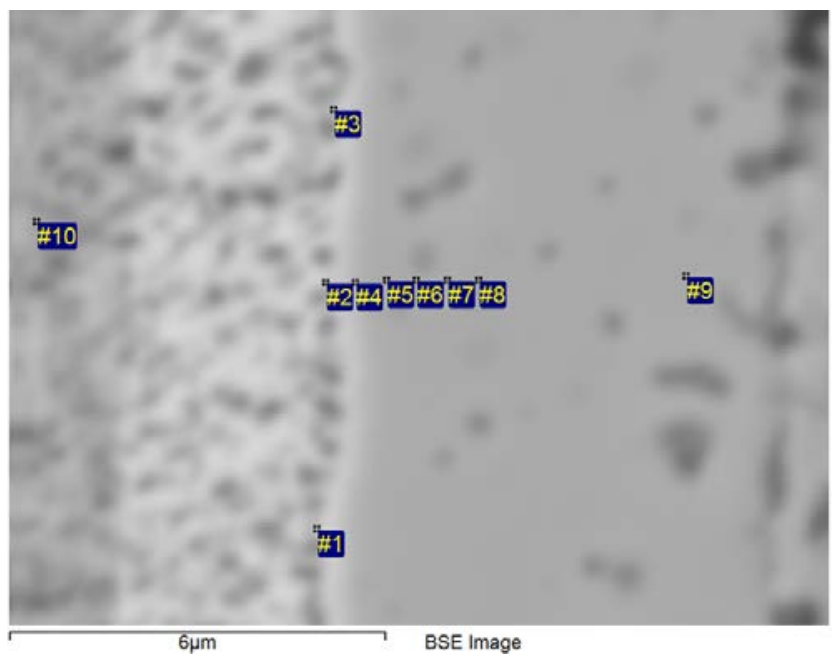

Figure 8. Location of EDS analysis of Sr through YSZ electrolyte layer 